\title{
Okul öncesi öğretmenliği programı ile sosyal hizmet bölümü öğrencilerinin problem çözme becerilerinin incelenmesi $^{*}$
}

\author{
Serap ERDOĞAN ${ }^{* *}$ \\ Eda PURUTÇUOĞLU***
}

\section{Özet}

Bu çalışma, okul öncesi öğretmenliği programı ile sosyal hizmet bölümü öğrencilerinin problem çözme becerilerinin incelenmesi amacıyla planlanmıştır. Çalışmaya, Ankara Üniversitesi Sağlık Bilimleri Fakültesi Sosyal Hizmet Bölümü ile Anadolu Üniversitesi Eğitim Fakültesi Okul Öncesi Öğretmenliği Bölümü birinci, ikinci, üçüncü ve dördüncü sınıfa devam eden öğrenciler dâhil edilmiştir. Araştırmada veri toplama aracı olarak Heppner ve Petersen (1982) tarafından geliştirilen "Problem Çözme Ölçeği” kullanılmıştır. Öğrencilerin problem çözme becerisini desteklemeye yönelik ders alma durumları, okudukları bölüm ve sınıf bağımsız değişkenler olarak belirlenmiş olup öğrencilere ilişkin genel bilgiler bölümünde frekans dağılımları gösterilmiştir. Öğrencilerin problem çözme becerisini desteklemeye yönelik ders alma durumları okudukları bölüme göre önemlilik testi (ki-kare) kullanılarak değerlendirilmiştir. Bunun yanı sıra, öğrencilerin problem çözme becerisini desteklemeye yönelik ders konusu işleme durumları ile okudukları bölümün problem çözme becerisi üzerindeki etkisini belirlemek amacı ile iki yönlü varyans analizi (ANOVA) uygulanmıştır. Araştırmada, öğrencilerin okudukları bölüme ve sınıfa göre problem çözme becerisini belirlemek amacı ile de t-testi ve parametrik olmayan testlerden Kruskal Wallis-H kullanılmıştır. Araştırma kapsamına alınan öğrencilerin ders konusu işleme durumları ile okudukları bölümün etkileşiminin problem çözme becerisi üzerindeki etkisinin anlamlı olduğu bulunmuştur $(\mathrm{p}<0.05)$. Problem çözmeye $(\mathrm{p}<0.01)$ ve planlı yaklaşmaya $(\mathrm{p}<0.001)$ yönelik becerilerinin okudukları bölüm değişkenine göre farklılık gösterdiği; okul öncesi öğretmenliğinde okuyan öğrencilerin problem çözme becerilerinin yetersiz olduğunu saptanmıştır. Sınıf değişkeni dikkate alındığında ise, problem çözme becerisinin alt boyutlarından olan problem çözme yeteneğine güvenme, planlı yaklaşım ve kişisel kontrol boyutları üzerinde öğrencilerin okudukları sınıfın etkisinin anlamlı olduğu görülmüştür. Buna göre, sınıf düzeyi arttıkça ortalama puanların düştüğü yani, problem çözme becerisinin arttı̆̆1 bulunmuştur $(\mathrm{p}<0.01)$. Öğrencilerin \%67,6’s1 daha önce ders kapsamında problem tanıma becerisini desteklemeye yönelik konular işlediklerini belirtmişlerdir.

Anahtar kelimeler: Eğitim süreci, problem çözme becerisi, okul öncesi eğitimi, sosyal hizmet

* Bu çalışmanın ilk hali, Öğretmen Eğitiminde Yeni Eğilimler Uluslararası Sempozyumu’nda (9-11 Mayıs 2013, Ankara) sözlü bildiri olarak sunulmuştur.

** Doç. Dr., Anadolu Üniversitesi, Eğitim Fakültesi, Okul Önceki Öğretmenliği Bölümü, serape@anadolu.edu.tr

*** Doç. Dr., Ankara Üniversitesi, Sağlık Bilimleri Fakültesi, Sosyal Hizmet Bölümü, purutcu@agri.ankara.edu.tr 


\title{
Investigating problem-solving skills of pre-school teaching programme students and social work students
}

\begin{abstract}
This research was planned and conducted to investigate the problem-solving skills of students working with special groups. By areas of expertise, in likely to their professional life, working in cooperation and coordination with social work students of the University of Ankara and preschool teaching programme students of the University of Anadolu were included in this study. The Problem Solving Scale was used to develop by Heppener and Petersen (1982). The status of taking problem solving skill course, department and the class of students were selected as an independent variables and their frequencies were shown in the general information part. The significance (chi-square test) was used to evaluate the courses which supporting the problem solving skills of students by department. By the way, two-way analysis of variance (ANOVA) was used to determine the impact of the status of taking courses about supporting the problem solving skills and the department on the problem-solving skills. On the other hand the t-test and Kruskal Wallis- $\mathrm{H}$ which is one of the non-parametric test was used to determine the problem solving skills by department and class. The meaningful differences were found between taking a problem solving skill course and department which they attend $(\mathrm{p}<0.05)$. Besides, it was found that the skills related to the planned approach $(\mathrm{p}<0.01)$ and problem solving $(\mathrm{p}<0.01)$ vary depending on the department where thet attend in. Furthermore, the students, attending pre-school teacher, was found an inadequate problem solving skills. Considering the class variable, trust the problemsolving skills, planned approach and personal control which is one of the dimensions of the problem-solving skills, has been shown to have significant effect on the class. According to this, it was established that as the class level increases, the problem-solving skills were found to increase $(\mathrm{p}<0.01)$. It was seen that as the degree of class increased, the mean scores fell. $67,6 \%$ of students stated that they committed some topics related to the problem solving skills.
\end{abstract}

Keywords: Education progress, problem-solving skill, pre-school teaching, social work

\section{Giriş}

Öğretmenler ve sosyal hizmet uzmanları hem eğitim-öğretim hem de müdahale süreçlerinde pek çok problemle karşılaşmaktadırlar. Bunların çözümüne yardımcı olacak bilgi ve becerileri hizmet öncesinde kazanmaları onların sınıflarında ve uygulamalarında karşılaşacakları özel durumlara yaklaşımlarının daha etkili ve verimli olmasını sağlayacaktır. Problem çözme becerisi günlük yaşamda karşılaşılan karmaşık problemleri çözme beceresi olarak tanımlanmaktadır (Sardoğan vd., 2006). Etkili olan problem çözme yollarının günlük yaşantı içinde öğrenilmesi her zaman mümkün olmayabilir. Bu durumda profesyonellerin bu becerileri sistemli olarak öğretmeleri gerekmektedir (Korkut, 2002). Problemlerin daha uygun ve daha kolay çözülmesini sağlayacak beceriler, problem temelli öğrenme yöntemi yoluyla sağlanabilir. Öğretmenler, öğrenmede meydana gelen sorunları araştıran ve çözebilen, bilgiyi arayıp bulan, kullanabilen, 
yüksek düzeyde düşünme becerisine sahip, analiz, sentez ve değerlendirme yapabilen bireyler olmak zorundadırlar. Bunun için, hizmet öncesinde öğretmen adaylarının aktif olarak öğrenme sürecine katılması gereklidir (Semerci, 2005). Bu konuda yapılan çalışma sonuçları, öğretmenlerin hizmet öncesi aldıkları eğitimin problem çözme becerilerini destekler nitelikte olduğunu göstermektedir (Yaman ve Yalçın, 2004; Pehlivan ve Konukman, 2004; Genç ve Kalafat, 2010; Çevik, 2011).

Okullar, okul öncesi dönemlerden itibaren bireylerin her açıdan gelişiminde, yetiştirilmesinde, nitelikli insangücü olarak toplumda yerlerini almalarını sağlamada önemli eğitim kurumlarıdır. Okul öncesi eğitim ortamlarında çocukların okula uyum ve okula düzenli devam etmelerine, eğitim hizmetlerinden beklenen düzeyde yararlanmalarına engel teşkil eden, öğrencilerin arkadaş ilişkilerini ve gelişimlerini olumsuz yönde etkileyen psikososyal sorunların çözümünde ve uygun biçimde ele alınmasında görev alabilecek disiplinlerden birisi de sosyal hizmet disiplinidir (Özbesler ve Duyan, 2009).

Günümüzün karmaşık ve sürekli değişen toplumsal yaşamında vazgeçilemez bir meslek olarak sosyal hizmet mesleği karşımıza çlkıyor. Sosyal hizmet mesleği, sosyal değişimi, insan ilişkilerinde problem çözmeyi ve refahı artırmak için insanın güçlenmesini ve özgürleşmesini destekler. En yalın haliyle sosyal hizmet, insanlara kendi sosyal çevreleri içinde ve gerekirse sosyal çevrelerini değiştirerek, maksimum düzeyde yardım etme işlevi görür. Dolayısıyla sosyal hizmetin temel özelliklerinden birisi problem çözme odaklı olmasıdır. Problem çözme, danışanın sorunlarını tanımlama, kavrama ve belirlenen sorunları çözmek için süreç içinde danışanla ilgilenme anlamına gelir. Uygulamada ise problem çözme, varsayım ve değerler grubuna, sosyal çevreye, insan ve çevresi arasındaki ilişkiye, insan ve sosyal davranışı hakkında bilgi setine ve yardım yöntemlerine dayanan karmaşı bir süreçtir (Sheafor ve Horejsi, 2014; Heinonen ve Spearman, 2010). Bu süreç boyunca "çevresi içerisinde birey" yaklaşımını kullanır. Dolayısıyla sosyal hizmet, hem bireysel hem de bireysel problemleri etkileyen sosyal problemler ile ilgilenir.

Okul öncesi dönem, yaşamın temelidir. Bu dönemde çocuklar çok hızlı büyürler ve bu gelişim alanlarında şaşırtıcı bir hızla yetkinleşirler. Erken yaşam deneyimleri çocuğun okula, öğrenmeye ve kendi becerilerine dair geliştireceği tutumları belirler ve okul başarısını etkiler. Okul öncesi dönemde olumlu deneyimler yaşayan çocuk okula, öğrenmeye ve kendi becerilerine dair olumlu tutumlar geliştirir. Çocuğun erken yaşta olumsuz deneyimler yaşaması ise onun bütün eğitim yaşamını etkileyecek problemler yaşamasına neden olabilir. Okul öncesi çağda olumsuz deneyimleri olan çocuğun özdeğerinin düşük olduğu, okulda ve okul sonrası yaşamda düşük başarı gösterdiği ve daha fazla davranış problemi sergilediği bilinmektedir (Milli Eğitim Bakanlı̆̆ı, 2013). Birbirinden farklı sosyo-ekonomik özelliklere sahip, farklı yaşam durumlarındaki ailelerden gelen öğrencilerin karşılaştığı sorunların ele alınmasında, sosyal çevrelerinin değerlendirilmesi, okul içinde öğretmenler ve psikolojik danışmanlar ile okul dışında da öğrencinin ailesi, tedavi kurumları, sosyal hizmet ve sosyal yardım kurumları ile işbirliği ve koordinasyonun sağlanmasında ekolojik perspektifi iyi kullanan sosyal hizmet disiplini göz ardı edilmeyecek önemli rollere sahiptir (Özbesler ve Duyan, 2009). Bu nedenle okul öncesi eğitim kurumlarında, ekip çalışması anlayışında daha iyi hizmet verilebilmesi için 
okul öncesi eğitimi öğretmenleri ile sosyal hizmet uzmanlarının işbirliği içerisinde mesleki çalışmalar yapması beklenmektedir. Araştırmanın özel gruplarla çalışan öğrencilerin meslek hayatlarında karşılaştıkları problemleri, aldıkları eğitim yoluyla çözebilmelerine dolayısıyla kendini algılayışlarını değerlendirmelerine ve problem çözme becerisini içeren ders konularının yer aldığı eğitim programların oluşturulmasına katkı sağlayacağı düşünülmektedir. Bu çalışma, okul öncesi öğretmenliği programı ile sosyal hizmet bölümü öğrencilerinin problem çözme becerisini desteklemeye yönelik ders konusu işleme durumlarının okudukları bölüm ve problem çözme becerileri üzerinde farklılık yaratıp yaratmadığını ve ayrıca ders işleme durumları ile sınıf değişkenlerinin problem çözme becerileri üzerindeki etkisini belirlemek amacıyla planlanmış ve yürütülmüştür.

\section{Yöntem}

\section{Araştırma modeli}

$\mathrm{Bu}$ araştırma ile özel gruplarla çalı̧acak okul öncesi öğretmenliği programı ile sosyal hizmet bölümü öğrencilerinin problem çözme becerileri ortaya çıkarılmaya çalışılmıştır. Araştırma, bu yönüyle betimsel bir araştırma özelliği taşımaktadır. Betimsel yöntem var olan bir olayı nicel ya da nitel yönden betimleyen bir araştırma türüdür. Geçmişte ve bugün var olan bir olay ya da durumu, var olduğu şekilde tanımlayan bir araştırmadır (Balcı, 1989). Bu amaca en uygun yöntem olduğu düşüncesiyle nicel araştırma yapılmıştır. Nicel araştırmalar nesnel, genellenebilir, geçerli ve güvenilir bilgi elde etme amacıyla genel teorilere ve bu teorilerden çıkarılan hipotezlere sahip olmakla kavramsallaştırılan olgu ve olayları gözlemlenebilir, ölçülebilir ve sayısal olarak ifade edilebilir bir şekilde ortaya koyan bir araştırma türüdür. Kısaca; nicel veri teknikleri, veri özetleyicileridir. Büyük resmi görmek için verileri özetlerler (Neuman, 2013).

\section{Çalışma grubu}

Araştırma evrenini, çalışma grubunu uzmanlık alanları gereği meslek hayatlarında işbirliği yapmaları ve koordinasyon içinde çalışmaları muhtemel olan sosyal hizmet ile okul öncesi öğretmenliği bölümlerinde okuyan öğrenciler oluşturmaktadır. $\mathrm{Bu}$ amaçla anılan bölümleri temsil ettikleri düşünülen Ankara Üniversitesi Sağlık Bilimleri Fakültesi Sosyal Hizmet Bölümü ile Anadolu Üniversitesi Eğitim Fakültesi Okul Öncesi Öğretmenliği programlarına devam eden öğrenciler araştırma kapsamına alınmıştır. Araştırma kapsamına alınacak denek sayısının saptanmasında tabakalı örnekleme tekniği kullanılmış olup öğrencilerin seçilmesinde tesadüfi örnekleme yöntemi kullanılmıştır. Araştırma, araştırmaya katılmayı kabul eden ve gönüllü 281 (140 sosyal hizmet, 141 okul öncesi öğretmenliği) öğrenci üzerinde yürütülmüştür. Genel toplamda öğrencilerin $\% 71,2$ 'si kız, \%28,8'i erkek öğrencidir. Araştırma kapsamına alınan öğrencilerin yarıdan fazlası (\%59,1) 18-20, \%35,6’sı 21-23 yaşlarında olup ortalama yaş 20,56 $\pm 1,93$ ’tür. Araştırmaya dahil edilen öğrencilerin \%42,7’si birinci sınıfa, \%29,5’si ikinci sınıfa, $\% 20,7$ ü üçüncü sınıfa ve \%7’i dördüncü sınıfa devam etmektedir. Çalışma kapsamına alınan öğrencilerin çoğunluğu $(\% 67,6)$ daha önce ders kapsamında problem çözme becerisini 
Marmara Üniversitesi Atatürk Eğitim Fakültesi Eğitim Bilimleri Dergisi / Journal of Educational Sciences YIl: Haziran 20I5 • Cilt-Sayı: 42 •ISSN: I300-8889 • ss. 223-237

desteklemeye yönelik konular işlediklerini belirtmiş olup bölüm açısından değerlendirildiğinde; sosyal hizmet öğrencilerinin \%69,3'ü, okul öncesi öğretmenliği öğrencilerinin \%66'sı "evet" yanıtını vermişlerdir (Bkz. Tablo 1).

Tablo I

Öğrencilere Ilişkin Genel Bilgiler

\begin{tabular}{|c|c|c|c|c|c|c|c|}
\hline & & \multicolumn{4}{|c|}{ Bölüm } & & \\
\hline \multirow{2}{*}{\multicolumn{2}{|c|}{ Genel Bilgiler }} & \multicolumn{2}{|c|}{$\begin{array}{l}\text { Sosyal Hizmet } \\
\text { Bölümü }\end{array}$} & \multicolumn{2}{|c|}{$\begin{array}{l}\text { Okul Öncesi } \\
\text { Öğretmenliği } \\
\text { Bölümüi } \\
\end{array}$} & \multicolumn{2}{|c|}{ Toplam } \\
\hline & & $\mathbf{n}$ & $\%$ & $\mathbf{n}$ & $\%$ & $\mathbf{n}$ & $\%$ \\
\hline \multirow{3}{*}{ Cinsiyet } & Kadın & 83 & 59.3 & 117 & 83.0 & 200 & 71.2 \\
\hline & Erkek & 57 & 40.7 & 24 & 17.0 & 81 & 28.8 \\
\hline & Toplam & 140 & 49.8 & 141 & 50.2 & 281 & 100.0 \\
\hline \multirow{5}{*}{ Yaş } & $18-20$ & 66 & 47.1 & 100 & 70.9 & 166 & 59.1 \\
\hline & $21-23$ & 67 & 47.9 & 33 & 23.4 & 100 & 35.6 \\
\hline & $24-26$ & 6 & 4.3 & 6 & 4.3 & 12 & 4.3 \\
\hline & $27->$ & 1 & 0.7 & 2 & 1.4 & 3 & 1.1 \\
\hline & Toplam & 140 & 100.0 & 141 & 100.0 & 281 & 100.0 \\
\hline \multirow{5}{*}{ Sinif } & Birinci & 62 & 44.3 & 58 & 41.1 & 120 & 42.7 \\
\hline & İkinci & 31 & 22.1 & 52 & 36.9 & 83 & 29.5 \\
\hline & Üçüncü & 47 & 33.6 & 11 & 7.8 & 58 & 20.6 \\
\hline & Dördüncü & 0 & 0.0 & 20 & 14.2 & 20 & 7.1 \\
\hline & Toplam & 140 & 100.0 & 141 & 100.0 & 281 & 100.0 \\
\hline \multirow{3}{*}{$\begin{array}{l}\text { Daha Önce Problem Çözme } \\
\text { Becerisini Desteklemeye } \\
\text { Yönelik Ders Konusu İşleme } \\
\text { Durumu }\end{array}$} & Evet & 97 & 69.3 & 93 & 66.0 & 190 & 67.6 \\
\hline & Hayır & 43 & 30.7 & 48 & 34.9 & 91 & 32.4 \\
\hline & Toplam & 140 & 100.0 & 141 & 100.0 & 281 & 100.0 \\
\hline
\end{tabular}




\section{Veri toplama aracı}

Araştırma materyalinin toplanmasında önceden yapılmış araştırmalardan yararlanılarak geliştirilen Genel Bilgi Formu ile Heppner ve Petersen (1982) tarafından geliştirilen "Problem Solving Inventory”, Form-A (PSI-A) olarak isimlendirilen, Şahin, Şahin ve Heppner (1993) tarafından Türkçeye uyarlanmış olan "Problem Çözme Ölçeği” kullanılmıştır. Öğrencilere ilişkin genel bilgilerin yer aldığg birinci bölümde, öğrencilerin okudukları bölüm, cinsiyeti, yaşı, devam ettikleri sınıf saptanmaya çalışılmıştır. Ayrıca daha önce ders kapsamında problem çözme sistematiğini ve tekniklerini kullanmayı ve etkin bir ekip çalışması ile neler yapılabileceğini içeren problem çözme becerisini desteklemeye yönelik konular işleyip işlemedikleri, soruya “evet” yanıtını verenlerin hangi beceri/becerilerinin desteklendiğini düşündükleri belirlenmeye çalışılmıştır. Araştırmanın ikinci bölümünde ise öğrencilerin problem çözme becerilerinin belirlenmesi amacı ile 35 maddeden oluşan ve (6) Her zaman böyle davranırım, (5) Çoğunlukla böyle davranırım, (4) Sık sık böyle davranırım, (3) Arada sırada böyle davranırım, (2) Ender olarak böyle davranırım, (1) Hiçbir zaman böyle davranmam şeklinde derecelendirilen "Problem Çözme Ölçeği”ne yer verilmiştir. Envanterden 32-192 arası puan alınabilir. Araştırmaya katılanların problem çözme beceri düzeyleri 3 gruba ayrılmış, ölçekten alınan toplam puan 32-85 arasında ise yüksek, 86-129 arasında ise orta ve 130-192 arasında ise düşük olarak değerlendirilmiştir. Ölçekten alınan toplam puanların yüksekliği, bireyin problem çözme becerileri konusunda kendisini yetersiz olarak algıladığını göstermektedir (Savaşır ve Şahin, 1997). Problem çözme ölçek puan ortalaması sosyal hizmet bölümünde 77,21, okul öncesi öğretmenliği bölümünde ise 84,77 olup yüksek düzeydedir. Ölçeğin, güvenirlik çalışması sonucunda Cronbach Alpha güvenirlik katsayısı .88 olarak bulunmuştur. Ölçeğe yapılan faktör analizi sonucunda "problem çözme yeteneğine güven”, "planlı yaklaşım”, "kişisel kontrol” ve "kaçıngan yaklaşım” olmak üzere dört alt faktör oluşturulmuştur. Çalışmamızda güvenirlik katsayılarının, problem çözme yeteneğine güven alt ölçeği için .88; planlı yaklaşım alt ölçeği için .81; kişisel kontrol alt ölçeği için .70; kaçıngan yaklaşım alt ölçeği için .73 olduğu görülmüştür.

\section{Verilerin analizi}

Araştırma sonucunda elde edilen bilgiler, SPSS 16.0 paket yazılım programından yararlanılarak oluşturulan veri tabanında toplanmıştır. Araştırma verileri, betimsel istatistik hesaplamaları yapılarak değerlendirilirken öğrencilerin problem çözme becerisini desteklemeye yönelik ders alma durumları, okudukları bölüm ve sınıf bağımsız değişkenler olarak ele alınmıştır. Öğrencilerin daha önce problem çözme becerisini desteklemeye yönelik aldıkları ders konusuna ilişkin başlıklar, okudukları bölüme göre önemlilik testi (ki-kare) kullanılarak değerlendirilmiştir. Öğrencilerin problem çözme becerisini desteklemeye yönelik ders konusu işleme durumları ile okudukları bölümün, problem çözme becerisi üzerindeki etkisini belirlemek amacı ile iki yönlü varyans analizi (ANOVA) uygulanmıştır. Araştırmada, öğrencilerin okudukları bölüme ve sınıfa göre problem çözme becerisini belirlemek amacı ile de t-testi ve parametrik olmayan testlerden Kruskal Wallis-H uygulanmıştır. 


\section{Bulgular}

Araştırma kapsamına alınan öğrenciler, eğer daha önce ders kapsamında problem çözme becerisini desteklemeye yönelik konular işlediler ise, konunun desteklediği başlıklara ilişkin frekans dağılımları Tablo 2'de verilmiştir.

\section{Tablo 2}

Öğrencilerin Daha Önce Problem Çözme Becerisini Desteklemeye Yönelik Aldıkları Ders Konusuna Illişkin Başliklar

\begin{tabular}{|c|c|c|c|c|c|c|c|c|}
\hline \multirow{2}{*}{$\begin{array}{l}\text { Ders Konusuna } \\
\text { İlişkin Başlıklar }\end{array}$} & \multirow{2}{*}{ Bölüm } & \multicolumn{2}{|c|}{ Evet } & \multicolumn{2}{|c|}{ Hayır } & \multicolumn{2}{|c|}{ Toplam } & \multirow{2}{*}{ İstatistik } \\
\hline & & $S$ & $\%$ & $S$ & $\%$ & S & $\%$ & \\
\hline \multirow[t]{2}{*}{ Eleştirel düşünme } & Sosyal hizmet & 68 & 55,7 & 72 & 45,3 & 140 & 100 & \multirow{3}{*}{$\begin{array}{c}\mathrm{x}^{2}=3,018 \\
\mathrm{p}>0.05\end{array}$} \\
\hline & $\begin{array}{l}\text { Okul öncesi } \\
\text { öğretmenliği }\end{array}$ & 54 & 44,3 & 87 & 54,7 & 141 & 100 & \\
\hline & Toplam & 122 & 43,4 & 159 & 56,6 & 281 & 100 & \\
\hline \multirow{2}{*}{$\begin{array}{l}\text { Problem çözme } \\
\text { süreçlerini tanıma }\end{array}$} & Sosyal hizmet & 67 & 47,9 & 73 & 52,1 & 140 & 100 & \multirow{3}{*}{$\begin{array}{c}x^{2}=2,618 \quad \text { sd: } 1 \\
\quad p>0.05\end{array}$} \\
\hline & $\begin{array}{l}\text { Okul öncesi } \\
\text { öğretmenliği }\end{array}$ & 54 & 38,3 & 87 & 61,7 & 141 & 100 & \\
\hline & Toplam & 121 & 43,1 & 160 & 56,9 & 281 & 100 & \\
\hline \multirow[t]{2}{*}{ Yaratıcı düşünme } & Sosyal hizmet & 63 & 45,0 & 77 & 55,0 & 140 & 100 & \multirow{3}{*}{ 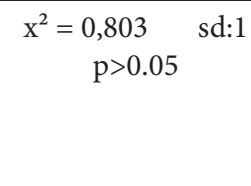 } \\
\hline & $\begin{array}{l}\text { Okul öncesi } \\
\text { öğretmenliği }\end{array}$ & 56 & 39,7 & 85 & 60,3 & 141 & 100 & \\
\hline & Toplam & 119 & 42,3 & 162 & 57,7 & 281 & 100 & \\
\hline \multirow{2}{*}{$\begin{array}{l}\text { Alan ile ilgili } \\
\text { problemleri tanıma }\end{array}$} & Sosyal hizmet & 59 & 42,1 & 81 & 57,9 & 140 & 100 & \multirow{3}{*}{$\begin{aligned} \mathrm{x}^{2}=10,313^{\star} & \mathrm{sd}: 1 \\
\mathrm{p}<0.05 & \end{aligned}$} \\
\hline & $\begin{array}{l}\text { Okul öncesi } \\
\text { öğretmenliği }\end{array}$ & 34 & 24,1 & 107 & 75,9 & 141 & 100 & \\
\hline & Toplam & 93 & 33,1 & 188 & 66,9 & 281 & 100 & \\
\hline \multirow{2}{*}{$\begin{array}{l}\text { Başarısızlığın } \\
\text { nedenlerini } \\
\text { araştırma }\end{array}$} & Sosyal hizmet & 50 & 35,7 & 90 & 64,3 & 140 & 100 & \multirow{3}{*}{$\mathrm{x}^{2}=3,429 \quad \mathrm{sd}: 1$} \\
\hline & $\begin{array}{l}\text { Okul öncesi } \\
\text { öğretmenliği }\end{array}$ & 36 & 25,5 & 105 & 74,5 & 141 & 100 & \\
\hline & Toplam & 86 & 30,6 & 195 & 69,4 & 281 & 100 & \\
\hline \multirow[t]{2}{*}{ Özgüven } & Sosyal hizmet & 47 & 33,6 & 93 & 66,4 & 100 & 100 & \multirow[t]{3}{*}{$\mathrm{x}^{2}=1,801 \quad \mathrm{sd}: 1$} \\
\hline & $\begin{array}{l}\text { Okul öncesi } \\
\text { öğretmenliği }\end{array}$ & 37 & 26,2 & 104 & 73,8 & 100 & 100 & \\
\hline & Toplam & 84 & 29,9 & 197 & 70,1 & 281 & 100 & \\
\hline \multirow{2}{*}{$\begin{array}{l}\text { Öngörü sahibi } \\
\text { olma }\end{array}$} & Sosyal hizmet & 42 & 30,0 & 98 & 70,0 & 100 & 100 & \multirow{3}{*}{$\begin{array}{c}\mathrm{x}^{2}=3,310 \quad \mathrm{sd}: 1 \\
\mathrm{p}>0.05\end{array}$} \\
\hline & $\begin{array}{l}\text { Okul öncesi } \\
\text { öğretmenliği }\end{array}$ & 29 & 20,6 & 112 & 79,4 & 100 & 100 & \\
\hline & Toplam & 71 & 25,3 & 210 & 74,7 & 281 & 100 & \\
\hline
\end{tabular}


Araştırma kapsamına alınan öğrencilerin problem çözme becerisini desteklemeye yönelik aldıkları ders konusuna ilişkin başlıklar incelendiğinde; "eleştirel düşünme" ve "problem çözme süreçlerini tanıma" yanıtını verdikleri $(\% 43,4, \% 43,1)$ bunu \%42,3 oranı ile "yaratıcı düşünme" seçeneğinin izlediği saptanmıştır (Bkz. Tablo 2). Yapılan ki-kare analizi sonuçlarına göre; sosyal hizmet ve okul öncesi öğretmenliği öğrencileri arasında "alan ile ilgili problemleri tanıma" durumu açısından fark istatistiksel olarak önemli bulunmuştur $(\mathrm{p}<0.05)$. Bu durum öğrencilerin okudukları bölümlere bağlı olarak sosyal hizmetin problemleri çözmek amacıyla problem çözme yaklaşımını kullanma odağında bir disiplin ve meslek olmasından kaynaklanabilir.

Öğrencilerin problem çözme becerisinin daha önce problem çözme becerisini desteklemeye yönelik ders konusu işleme durumları ile okudukları bölüme bağlı olarak anlamlı farklılık gösterip göstermediği iki yönlü varyans analizi (ANOVA) ile değerlendirilmiştir (Bkz. Tablo 3).

Tablo 3

Öğrencilerin Problem Çözme Becerisini Desteklemeye Yönelik Ders Konusu İşleme Durumları ile Okudukları Bölümün Problem Çözme Becerisi Üzerindeki Etkisine Illişkin İki Yönlü ANOVA Değerleri

\begin{tabular}{|c|c|c|c|c|c|c|c|c|}
\hline $\begin{array}{c}\text { Ders İşleme } \\
\text { Durumu }\end{array}$ & Bölüm & $\mathbf{n}$ & \multicolumn{3}{|c|}{$\bar{x}$} & \multicolumn{3}{|c|}{$S$} \\
\hline \multirow{3}{*}{ Evet } & Sosyal hizmet & 97 & \multicolumn{3}{|c|}{76.9278} & \multicolumn{3}{|c|}{20.41407} \\
\hline & $\begin{array}{l}\text { Okul öncesi } \\
\text { öğretmenliği }\end{array}$ & 93 & \multicolumn{3}{|c|}{80.0000} & \multicolumn{3}{|c|}{19.26249} \\
\hline & Toplam & 190 & \multicolumn{3}{|c|}{78.4316} & \multicolumn{3}{|c|}{19.86603} \\
\hline \multirow{3}{*}{ Hayır } & Sosyal hizmet & 43 & \multicolumn{3}{|c|}{80.4884} & \multicolumn{3}{|c|}{15.98120} \\
\hline & $\begin{array}{l}\text { Okul öncesi } \\
\text { öğretmenliği }\end{array}$ & 48 & \multicolumn{3}{|c|}{94.0625} & \multicolumn{3}{|c|}{16.92965} \\
\hline & Toplam & 91 & \multicolumn{3}{|c|}{87.6484} & \multicolumn{3}{|c|}{17.75661} \\
\hline \multirow{3}{*}{ Toplam } & Sosyal hizmet & 140 & \multicolumn{3}{|c|}{78.0214} & \multicolumn{3}{|c|}{19.17562} \\
\hline & $\begin{array}{l}\text { Okul öncesi } \\
\text { öğretmenliği }\end{array}$ & 141 & \multicolumn{3}{|c|}{84.7872} & \multicolumn{3}{|c|}{19.61552} \\
\hline & Toplam & 281 & \multicolumn{3}{|c|}{81.4164} & \multicolumn{3}{|c|}{19.65727} \\
\hline \multicolumn{3}{|c|}{ Varyansın Kaynağı } & KT & sd & KO & $\mathbf{F}$ & $\mathbf{p}$ & $\eta^{2}$ \\
\hline \multicolumn{3}{|l|}{ Bölüim } & 4253,175 & 1 & 4253,175 & 11,980 & 0.001 & 0.041 \\
\hline \multicolumn{3}{|c|}{ Ders konusu işleme durumu } & 4766,940 & 1 & 4766,940 & 13,427 & 0.000 & 0.046 \\
\hline \multicolumn{3}{|c|}{ Bölüm/Ders konusu işleme durumu } & 1692,853 & 1 & 1692,853 & 4,768 & 0.030 & 0.017 \\
\hline \multicolumn{3}{|l|}{ Hata } & 98340,052 & 277 & 355,018 & & & \\
\hline \multicolumn{3}{|l|}{ Toplam } & 1970883,000 & 281 & & & & \\
\hline
\end{tabular}

a. R Squared $=0,091$ (Ajusted R Squared $=0.081$ ) 
Tablo 3 incelendiğinde, öğrencilerin ders konusu işleme durumları ile okudukları bölümün etkileşiminin problem çözme becerisi üzerindeki etkisinin anlamlı olduğu söylenebilir ( $\mathrm{p}<0.05)$. Ancak bu etkinin çok büyük olmadığı görülmektedir. Çünkü bu etkileşimin problem çözme becerisi üzerindeki etkisi \%2 civarındadır. Bununla birlikte, bölüm satırındaki anlamlılık değeri $(\mathrm{p}<0.04)$ problem çözme becerisi ile okudukları bölüm arasındaki ilişkinin $\mathrm{p}<0.05$ düzeyinde istatistiksel olarak anlamlı olduğunu ortaya koymakla birlikte tablonun ders konusu işleme durumu satırındaki anlamllık değeri de $\mathrm{p}<0.05$ düzeyinde istatistiksel olarak anlamlı bir farkllık göstermiştir. Diğer bir ifade ile öğrencilerin problem çözme becerileri okudukları bölüm ve ders konusu işleme durumlarına bağlı olarak ayrı ayrı anlamlı bir farklılık yaratmaktadır. Bu bulgu ışığında, tanımlayıcı istatistik tablosundaki toplam verilerle birlikte değerlendirildiğinde, öğrencilerin problem çözme becerilerinin problem çözme becerisini desteklemeye yönelik konular işlemediklerinde yetersiz olduğunu ortaya koymaktadır. Sosyal hizmet bölümünde okuyan öğrenciler arasında problem çözme becerisini desteklemeye yönelik ders alanların ortalama puanlarının okul öncesi öğretmenliğinde okuyan öğrencilere göre daha düşük dolayısıyla daha yeterli olduklarını göstermektedir.

Araştırmaya katılan öğrencilerin problem çözme becerisinin alt ölçekleri olan "problem çözme yeteneğine güvenme", "planlı yaklaşım", "kişisel kontrol" ve "kaçıngan yaklaşım" açısından okudukları bölümün etkisi Tablo 4’te verilmiştir.

Tablo 4

Öğrencilerin Okudukları Bölüme Göre Problem Çözme Becerisi Alt Ölçeklerine Illişkin t-Testi Sonuçları

\begin{tabular}{|c|c|c|c|c|c|c|}
\hline & Bölüm & $\mathbf{n}$ & $\bar{x}$ & $S$ & sd & $\mathbf{t}$ \\
\hline \multirow{2}{*}{$\begin{array}{l}\text { Problem çözme } \\
\text { yeteneğine güvenme }\end{array}$} & Sosyal hizmet & 140 & 29.7286 & 9.8052 & \multirow[b]{2}{*}{279} & \multirow[b]{2}{*}{$2.614^{* *}$} \\
\hline & $\begin{array}{l}\text { Okul öncesi } \\
\text { öğretmenliği }\end{array}$ & 141 & 32.8794 & 10.3961 & & \\
\hline \multirow[b]{2}{*}{ Planlı yaklaşım } & Sosyal hizmet & 140 & 13.9071 & 4.7874 & \multirow[b]{2}{*}{279} & \multirow[b]{2}{*}{$3.209^{*}$} \\
\hline & $\begin{array}{l}\text { Okul öncesi } \\
\text { öğretmenliği }\end{array}$ & 141 & 15.8865 & 5.5293 & & \\
\hline \multirow[b]{2}{*}{ Kişisel kontrol } & Sosyal hizmet & 140 & 19.9714 & 4.9018 & \multirow[b]{2}{*}{279} & \multirow[b]{2}{*}{0.880} \\
\hline & $\begin{array}{l}\text { Okul öncesi } \\
\text { öğretmenliği }\end{array}$ & 141 & 20.5177 & 5.4819 & & \\
\hline \multirow[b]{2}{*}{ Kaçıngan yaklaşım } & Sosyal hizmet & 140 & 14.4143 & 5.0764 & \multirow[b]{2}{*}{279} & \multirow[b]{2}{*}{1.801} \\
\hline & $\begin{array}{l}\text { Okul öncesi } \\
\text { öğretmenliği }\end{array}$ & 141 & 15.5035 & 5.0614 & & \\
\hline
\end{tabular}

${ }^{*} \mathrm{p}<0.01,{ }^{* *} \mathrm{p}<0.05$

Tablo 4’te görüldüğü gibi, öğrencilerin problem çözme becerisi okudukları bölüme göre incelendiğinde, okul öncesi öğretmenliği bölümü öğrencilerinin problem çözme yeteneğine güvenme [ $\left.\mathrm{t}_{279}=2.614, \mathrm{p}<0.05\right]$ ve planlı yaklaşım [ $\left.\mathrm{t}_{279}=3.209, \mathrm{p}<0.01\right]$ alt ölçeklerine yönelik 
ortalama puanlarının, sosyal hizmet bölümü öğrencilerinden daha yüksek olduğu bulunmuştur. Bu bulgu, okul öncesi öğretmenliği bölümünde okuyan öğrencilerin problem çözme becerilerinin yetersiz olduğunu göstermektedir. Bu durum, daha özel ve nispeten küçük grupla çalışıyor olmaları ve gruba ilişkin problemlerin benzerlik göstermesinden kaynaklanabilir. Buna göre, sosyal hizmet bölümü öğrencilerinin kendilerini problem çözme yeteneğine güvenmede ve planlı yaklaşımda daha yeterli gördükleri söylenebilir. Sosyal hizmet, insani ilişkilerdeki problem çözmeyi, insanların refahı için özgür olmalarını ve güçlenmelerini sağlayan, destekleyen ve insanların çevresiyle karşılıklı etkileşimde bulunduğu noktalarda müdahale eden bir meslektir. Analiz sonucunda çıkan farklılığın nedeni, sosyal hizmet bölümünde okuyan öğrencilerin bireyin problem çözme motivasyonunun arttırılması, kendi güçlü yanlarıyla problem çözme sürecine katılmasının sağlanması, gereksinim duyduğu hizmet ve kaynakları kullanabilecek güçte olmasının sağlanması konularında eğitim almalarından kaynaklanabilir. Kişisel kontrol ve kaçıngan yaklaşım alt ölçekleri değerlendirildiğinde ise, istatistiksel olarak anlamlı bir farklılık bulunmamıştır ( $\mathrm{p}>0.05)$.

Araştırma kapsamına alınan öğrencilerin "problem çözme yeteneğine güvenme”, "planlı yaklaşım", "kişisel kontrol" ve "kaçıngan yaklaşım" alt boyutlarında oluşan problem çözme becerisi okudukları sınıfa bağlı olarak anlamlı farklılık gösterip göstermediği Tablo 5’te verilmiştir.

Tablo 5

Öğrencilerin Okudukları Sınıfa Göre Problem Çözme Becerisi Alt Ölçeklerine Illişkin Kruskal Wallis-H Sonuçları $(n=28$ I)

\begin{tabular}{|c|c|c|c|c|c|}
\hline & Sinif & $\mathbf{n}$ & $\bar{X}$ & Df & İstatistiksel Analiz \\
\hline \multirow{4}{*}{ Problem çözme yeteneğine güvenme } & Birinci & 120 & & \multirow{4}{*}{3} & \multirow{4}{*}{$\begin{array}{c}\text { KWH }\left(\chi^{2}\right) \text { : } \\
11.351^{\star}\end{array}$} \\
\hline & İkinci & 83 & & & \\
\hline & Üçüncü & 58 & & & \\
\hline & Dördüncü & 20 & & & \\
\hline \multirow{4}{*}{ Planlı yaklaşım } & Birinci & 120 & & \multirow{4}{*}{3} & \multirow{4}{*}{ KWH $\left(\chi^{2}\right): 15.859^{*}$} \\
\hline & İkinci & 83 & & & \\
\hline & Üçüncü & 58 & & & \\
\hline & Dördüncü & 20 & & & \\
\hline \multirow{4}{*}{ Kişisel kontrol } & Birinci & 120 & & \multirow{4}{*}{3} & \multirow{4}{*}{$\mathrm{KWH}\left(\chi^{2}\right): 16.995^{\star}$} \\
\hline & İkinci & 83 & & & \\
\hline & Üçüncü & 58 & & & \\
\hline & Dördüncü & 20 & 95.72 & & \\
\hline \multirow{4}{*}{ Kaçıngan yaklaşım } & Birinci & 120 & & \multirow{4}{*}{3} & \multirow{4}{*}{ KWH $\left(\chi^{2}\right): 3.981$} \\
\hline & İkinci & 83 & & & \\
\hline & Üçüncü & 58 & & & \\
\hline & Dördüncü & 20 & & & \\
\hline
\end{tabular}

${ }^{*} \mathrm{p}<0.01$ 
Araştırma bulgularına göre problem çözme becerisinin alt boyutlarından olan problem çözme yeteneğine güvenme, planlı yaklaşım ve kişisel kontrol boyutları üzerinde öğrencilerin okudukları sınıfın etkisinin anlamlı olduğu saptanmıştır $\left[\chi^{2}(3)=11.351, p<0,01 ; \chi^{2}(3)=15.859\right.$, $\left.\mathrm{p}<0,01 ; \chi^{2}(3)=16.995, \mathrm{p}<0,01\right]$. Bu sonuçlara göre, problem çözme ölçeğinin özelliği nedeni ile ortalamaların düşmesi, problem çözme becerisinin arttığını gösterir. Sınıf düzeyi arttıkça ortalama puanların düştüğü yani, problem çözme becerisinin arttı̆̆ bulunmuştur. Bu durum sınıf düzeyi arttıkça öğrenilmiş becerilerin devreye girmesinden ve bilgiyi kullanmada daha akılcı davranılmasından kaynaklanabilir.

\section{Tartışma}

Araştırmada elde edilen bulgular genel olarak değerlendirildiğinde, özellikle birinci ve ikinci sınıfın problem çözme becerisi kazandırılması açısından farklılık yaratan önemli bir dönem olduğu görülmüștür. Her yll bir yaş daha büyüme ve yeni bir sinıfa geçme öğrencilerin problem çözme düzeyleri üzerinde farklılaşma yarattığını ortaya koymaktadır. Çalışmada, problem çözme becerisini desteklemeye yönelik ders konusu işleme durumu, en akılcı çözüm yolunun ne olduğu ve nasıl davranılması gerektiği konusunda farkllılk yaratan önemli bir değişken olarak görülmektedir. Bölüm değişkeni dikkate alındığında, sosyal hizmet bölümü öğrencilerinin problem çözme becerilerinin okul öncesi öğretmenliği bölümü öğrencilerine göre nispeten daha yeterli olduğu bulunmuştur. Sınıf değişkenine göre değerlendirildiğinde, sinıf düzeyi yükseldikçe problem çözme beceri puanları istatistiksel olarak anlamlı düzeyde düşüş göstermektedir. Dolayısıyla bu durum, sınıf düzeyi arttıkça bireyin problem çözme becerisinde de artışı göstermektedir. Bununla birlikte problem çözme becerisi; algılanan sosyal destek, etkili problem çözmeyi hedef alan eğitim, iç kontrollü davranış özelliği, cinsiyet, anne ve baba eğitim düzeyi gibi değişkenlerle ilişkili bir beceridir (Kanbay ve ark., 2013).

Yapılan çalışmalar incelediğinde, D’Zurilla ve arkadaşları (1998) çalışmalarında gençlikten orta yaşa doğru ilerledikçe problem çözme becerilerinin arttığını, yaşlılık döneminde azaldığını saptamışlardır. Kaptan ve Korkmaz (2002), öğretmen adaylarının hizmet öncesi aldıkları eğitim ile ilgili araştırmalarında hizmet öncesi ilköğretim sınıf öğretmenleri ile fen bilgisi öğretmenlerinin problem çözme yeterliklerine yönelik algılarını inceledikleri çalışmada, hizmet öncesi sınıf öğretmenleri ile fen bilgisi öğretmenlerinin aldıkları dersler ve derslerin özelliklerinin öğrencilerin problem çözme becerilerini etkilediğini saptamışlardır. Yaman ve Yalçın (2004) yaptıkları bir araştırmada, Fen Bilgisi öğretiminde probleme dayalı öğretim (PDÖ) yaklaşımının öğretmen adaylarının yaratıcı düşünme düzeylerine etkisini değerlendirilmişlerdir. Araştırma sonunda, deney grubundaki öğretmen adaylarının yaratıcı düşünme düzeylerinin kontrol grubundaki öğrencilerden daha fazla geliştiği görülmüştür. Pehlivan ve Konukman (2004) beden eğitimi öğretmenleri ile diğer branş öğretmenlerinin problem çözme becerisindeki algılama düzeylerini araştırdıkları çalışmada, beden eğitimi öğretmenlerinin sporcu geçmişleri, sosyalleşmeleri ve aldıkları eğitimin sonucunda, sportif bir yaşam biçimiyle iç içe olduklarından dolayı, diğer öğretmen gruplarına göre karşılaşılan sorunları çözme beceri düzeylerinin olumlu 
yönde farklı olduğunu saptamışlardır. Genç ve Kalafat (2007), öğretmen adaylarının demokratik tutumları ile problem çözme becerilerinin farklı değişkenler açısından değerlendirdikleri çalı̧mada, öğretmen adaylarının problem çözme becerilerinin öğrenim gördükleri sınıfa göre anlamlı bir farklılık gösterdiğini, sınıf düzeyi yükseldikçe problem çözme becerisinin de arttığını ve farklılığın dördüncü sınıf öğrencilerinden kaynaklandığını saptamışlardır. Ancak Altunçekiç, Yaman ve Koray (2005) çalışmalarında, öğretmen adaylarının problem çözme becerilerinin eğitim gördükleri alanlara göre farklılaşmadığını, sınıf düzeylerinin problem çözme becerilerini anlamlı olarak etkilemediğini belirlemişlerdir. Çınar ve arkadaşları (2009) öğretmenlerin kendi algılarına göre problem çözme beceri düzeylerini belirlemeye ilişkin çalışmalarında, öğretmenlerin meslekte çalışma süresinin istatistiksel olarak anlamlı bir farklılık yaratmadığını; ancak alt ölçek ortalama puanları değerlendirildiğinde, meslekte çalı̧ma süresi arttıkça ortalama puanların az da olsa arttığını saptamışlardır. Buna göre meslekte yeni olan öğretmenlerin kendilerini problem çözmede biraz daha becerikli olarak değerlendirdikleri bulunmuş olup bu durum, genç öğretmenlerin değişime daha kolay ayak uydurabildikleri ve bu açıdan sorunları daha kolay çözdükleri ile açıklanmaktadır. Bağçeci ve Kınay (2013) ise, öğretmenlerin problem çözme ölçeğinden aldıkları puanların cinsiyete ve branşa göre anlamlı bir farklılık yaratmadığını; ancak hizmet süresine göre "kişisel kontrol" ve "problem çözme yeteneğine güvenme" boyutlarında anlamlı bir farklılık olduğunu bulmuşlardır. Genç ve Kalafat (2010), öğretmen adaylarının empatik eğilimlerini ve problem çözme becerilerini farklı değişkenler açısından inceledikleri çalışmada, 3 . sınıf öğretmen adayları problem çözme becerileri bakımından, kendilerini 4. sınıf öğrencilerine göre daha başarılı görürken, empatik becerilerde anlamlı bir fark bulunamamıştır. Çevik (2011), müzik öğretmeni adaylarının problem çözme becerilerinin çeşitli değişkenler açısından değerlendirdiği çalışmasında, öğretmen adaylarının ileriki meslek yaşantılarında karşılaştıkları sorunların üstesinden gelebilmeleri ve güçlükler karşısında yılmamaları adına problem çözme becerilerinin geliştirilmesinin gerekliliğini ortaya koymuştur. Özkan ve arkadaşları (2013), sosyal hizmet bölümü öğrencilerinin çeşitli değişkenlere göre kişilerarası problem çözme becerilerini inceledikleri çalışmada, yaş arttıkça öğrencilerin daha fazla yapıcı problem çözme özelliğine sahip olduklarını, kız öğrencilerin problemlere daha fazla olumsuz yaklaştıklarını belirlemişlerdir.

Problem çözme becerisi, eleştirel düşünmeyi ya da inandırıcı argümanlar geliştirmeyi, bilgi organizasyonunu ve yaratıcılığı içermektedir. Dolayısıyla öğrencilerin bir argüman geliştirmesi için disiplin ve yöntem bilgisine ihtiyacı vardır. D’Zurilla ve Nezu (2007), bireylerin stres kaynaklarını yeniden düşünmelerini ve sorunları belirlemelerini sağlayan tutum, tanımlama, seçenekler, tahmin ve deneyim olmak üzere problem çözme yaklaşımına ilişkin dört adımı önermektedir. Buna göre birey, öncelikle karşı karşıya kaldığı sorun/sorunları tanımlamalı, alternatif çözüm listesi oluşturmalı ve her bir alternatifin artılarını ve eksilerini tartarak etkin olması en muhtemel çözümü uygulamalıdır. Bu yapısal yaklaşım, bireylere gelecekteki sorunların üstesinden gelebileceği bir beceri setini öğretir.

Problem çözme sürecinde başarılı olmak için gerekli olanlar güven, zaman, enerji ve temel iletişim becerileridir. Özellikle, kendine güven ve risk alma için istekli olma problem çözücüler için zorunludur. Problem çözme becerisinin yetersizliği ise kaliteyi, değişimi, meslekte 
profesyonelliği, otonomi ve güç sahibi olmayı olumsuz yönde etkilemektedir. Bu nedenle, eğitimcilerin ve okul yöneticilerinin müfredat programlarında öğrencilerin problem çözme eğilimlerini değerlendirebileceği hem bilişsel gelişimi hem de başa çıkmayı etkileyecek davranışsal değişimi hedefleyen derslere/konulara ilk yıllardan itibaren yer vermesi önemlidir. Bu kapsamda probleme dayalı öğrenme modelinin ağırlıkta olduğu eğitimin yaygınlaştırılması önerilebilir. Öğrencilerin problemden ne anladıklarını kendi ifadeleri ile anlattırılması, gerektiğinde soru-cevap yöntemi ile öğrencilerin yönlendirilmesi ve durumun anlaşlıp anlaşılmadığının kontrolünün yapılması ile sağlanabilir. Özellikle okul öncesi öğretmenliği bölümünde okuyan öğrencilerin, daha fazla problem çözmeyi temel alarak oluşturulan senaryolarla küçük gruplarda çalışması desteklenmelidir. Sosyal hizmet bölümü öğrencilerinin ise problem çözme becerilerini sürekli olarak kullanmaları beklendiği için ihtiyaçlara yanıt verebilme, güvenilir ve geçerli bir değerlendirme sağlama, müdahalelerinde iletişim kurma ve geliştirme sorumluluğu bulunmaktadır. Bu kapsamda sosyal hizmet müdahalelerinde müdahale çabalarının etkinliğini ve değerlendirmesini artırmak için eleştirel düşünme yöntemlerine daha fazla ağırlık verilmesi, okuma yapma ve sınıf içi tartışmaların desteklenmesi gerekmektedir. Benzer biçimde karar verme becerilerinin de beceri eğitimi yolu ile geliştirilebileceği dikkate alındığında, etkili problem çözme becerilerinin öğretilebileceği ve etkili olabileceği kapsamlı gelişimsel eğitim programlarının özellikle problem çözme odaklı meslek gruplarının eğitiminde yaygın olarak kullanılması gerekliliği bir kez daha ortaya çıkmaktadır. klasik öğretim yöntemlerinin yanı sıra öğrencinin öğretime aktif olarak katıldığı ve içerik temelli olarak eleştirel düşünmenin de konulara entegre edildiği öğretim yöntemlerinin daha sıklıkla kullanılarak problem çözme becerilerini diğer alanlara ve yaşamına aktarmaları beklenmektedir. 


\section{Kaynaklar}

Altunçekiç, A., Yaman, S. \& Koray, Ö. (2005). Öğretmen adaylarının öz-yeterlik inanç düzeyleri ve problem çözme becerileri üzerine bir araştırma (Kastamonu ili örneği). Kastamonu Eğitim Dergisi, 13(1), 93-102.

Bağçeci, B. \& Kınay, İ. (2013). Öğretmenlerin problem çözme becerilerinin bazı değişkenlere göre incelenmesi. Elektronik Sosyal Bilimler Dergisi, 12(44), 335-347.

Balcı, A. (1989). Eğitimsel araştırmanın eğitimsel sorunların çözümüne uygulanması. Ankara Üniversitesi Ĕ̆itim Bilimleri Fakültesi Dergisi, 22(1),411-420.

Çevik, D. (2011). Müzik öğretmeni adaylarının çeşitli değişkenlere göre problem çözme becerileri, Kastamonu Ĕ̆itim Dergisi, 19(3), 1003-1012.

Çınar, O., Hatunoğlu, A. \& Hatunoğlu, Y. (2009). Öğretmenlerin problem çözme becerileri. Erzincan Eğitim Fakültesi Dergisi, 11(2), 215-226.

D’Zurilla, T.J., Olivares-Maydeu, A. \& Kant, G.L. (1998). Age and gender differences in social problemsolving ability. Personality and Individual Differences, 25, 241-252.

D’Zurilla, T.J., \& Nezu, A. (2007). Problem solving theory-A positive approach to clinical intervention. 3rd ed. Springer Publishing Company; New York, New York.

Genç, Z. S. \& Kalafat, T. (2010). Öğretmen adaylarının empatik becerileri ile problem çözme becerileri. Kuramsal Eğitimbilim, 3(2), 135-147.

Genç, Z.S. \& Kalafat, T. (2007). Öğretmen adaylarının demokratik tutumları ile problem çözme becerilerinin çeşitli değişkenler açısından incelenmesi. Pamukkale Üniversitesi Eğitim Fakültesi Dergisi, 2(22), $10-22$.

Heinonen, T. \& Spearman, L. (2010). Social work practice-Problem solving and beyond (3rd Edition). MacMillan Publishing, Canada.

Kanbay, Y., Aslan, Ö., Işık, E. \& Kılıç, N. (2013). Hemşirelik lisans öğrencilerinin problem çözme ve eleştirel düşünme becerileri. Yükseköğretim ve Bilim Dergisi, 3(3), 244-251

Kaptan, F. \& Korkmaz, H. (2002). Türkiye’de hizmet öncesi öğretmenlerin problem çözme becerilerine yönelik algıları üzerine bir inceleme [A study on the perception towards to pre-service teachers' problem solving skills]. Journal of Qafqaz Universit, 9 (Spring), 183-188.

Korkut, F. (2002). Lise öğrencilerinin problem çözme becerileri. Hacettepe Üniversitesi Eğitim Fakültesi Dergisi, 22, 177-184.

Milli Eğitim Bakanlığı Temel Eğitim Genel Müdürlüğü (2013). Okul öncesi eğitimi programı. Ankara.

Neuman, W.L. (2013). Toplumsal araştırma yöntemler-Nitel ve nicel yaklaşımlar (1.Cilt). (Çev. Sedef Özge). Yayın Odası Ltd.Şti.

Özbesler, C. \& Duyan, V. (2009). Okul ortamlarında sosyal hizmet. Eğitim ve Bilim, 34(154), 17-25.

Özkan, Y., Akgün, R., Yanardağ Zubaroğlu, M. \& Yüceer, T. (2013). Sosyal hizmet öğrencilerinin bazı değişkenlere göre kişilerarası problem çözme becerilerinin incelenmesi. Türkiye Sosyal Araştırmalar Dergisi, 17(3), 197-213.

Pehlivan, Z. \& Konukman, F. (2004). Beden eğitimi öğretmenleri ile diğer branş öğretmenlerinin problem çözme becerisi açısından karşılaştırılması. Beden Eğitimi ve Spor Bilimleri Dergisi, 11(2), 55-60.

Sardoğan, M.E., Karahan, T.F. \& Kaygusuz, C. (2006). Üniversite öğrencilerinin kullandıkları kararsızlık stratejilerinin problem çözme becerisi, cinsiyet, sınıf düzeyi ve fakülte türüne göre incelenmesi. Mersin Üniversitesi Eğitim Fakültesi Dergisi, 2(1), 78-97.

Semerci, N. (2005). Problem temelli öğrenme ve öğretmen yetiştirme. Milli Eğitim, 33(166), 248-256.

Sheafor, B.W. \& Horejsi, C.J. (2014). Sosyal hizmet uygulamast-Temel teknikler ve ilkeler (Çev. Ed. Durdu Baran Çifci). Nika Yayınları, Ankara. 
Savaşır, I. \& Şahin, N.H. (1997). Bilişsel davranış̧̧ı terapilerde değerlendirme: Sık kullanılan ölçekler. Ankara: Türk Psikologlar Derneği Yayınları.

Şahin, N., Şahin, H.N. \& Heppner, P.P. (1993). Psychometric properties of the problem solving inventory in a group of turkish university students. Cognitive Theraphy and Research, 17(4), 379-396.

Yaman, S. \& Yalçın, N. (2004). Fen bilgisi öğretiminde probleme dayalı öğrenme yaklaşımının yaratıcı düşünme becerisine etkisi. İlköğretim-[online], 4(1), 42-52. 
